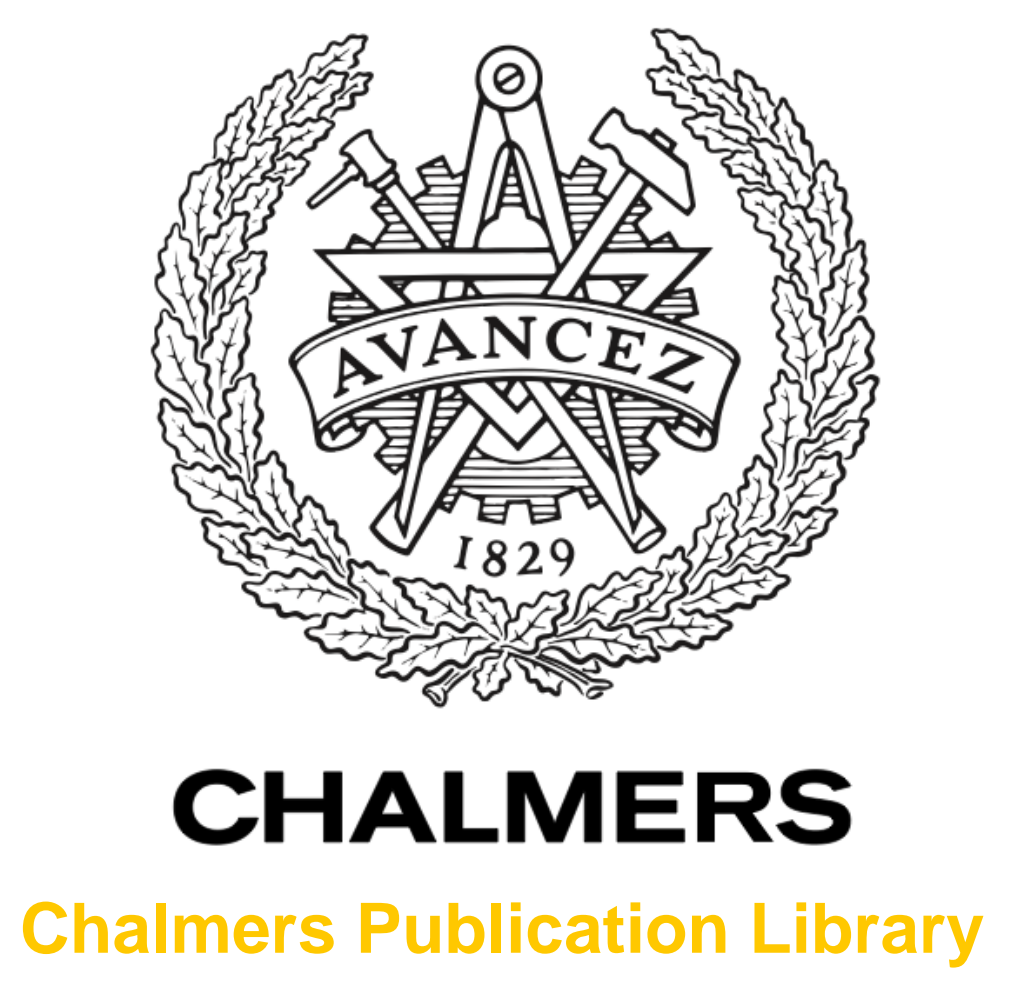

\title{
Organisational value of participating in a quality award process: a Swedish study
}

This document has been downloaded from Chalmers Publication Library (CPL). It is the author's version of a work that was accepted for publication in:

The TQM Magazine (ISSN: 0954-478X)

Citation for the published paper:

Eriksson, H. (2004) "Organisational value of participating in a quality award process: a

Swedish study". The TQM Magazine, vol. 16(2), pp. 78-92.

http://dx.doi.org/10.1108/09544780410522973

Downloaded from: http://publications.lib.chalmers.se/publication/148965

Notice: Changes introduced as a result of publishing processes such as copy-editing and formatting may not be reflected in this document. For a definitive version of this work, please refer to the published source. Please note that access to the published version might require a subscription.

Chalmers Publication Library (CPL) offers the possibility of retrieving research publications produced at Chalmers University of Technology. It covers all types of publications: articles, dissertations, licentiate theses, masters theses, conference papers, reports etc. Since 2006 it is the official tool for Chalmers official publication statistics. To ensure that Chalmers research results are disseminated as widely as possible, an Open Access Policy has been adopted.

The CPL service is administrated and maintained by Chalmers Library. 


\title{
Organisational Value of Participating in a Quality Award Process: a Swedish Study
}

by

\author{
Henrik Eriksson
}

\begin{abstract}
Division of Quality and Environmental Management, Luleå University of Technology, SE-971 87 Luleå, Sweden, +46920 491720, henrik.eriksson@ies.luth.se
\end{abstract}

Keywords: Quality Awards, Self-assessment, Organisational Values, Quality Award Process, Core Values, Experiences, TQM.

\begin{abstract}
One way for organisations to support Total Quality Management (TQM) and its values, methodologies and tools, and hence try to increase customer satisfaction is to participate in a quality award process. Many previous studies investigating the organisational value of participating in a quality award have focused on quality award recipients. However, most of the organisations applying for a quality award do not receive any award. Instead, one of the main incentives of participating in a quality award process can be the identification of improvement areas, which can later be transformed into actual improvements. The executed improvements can result in, for example, a greater customer orientation, more effective and efficient processes, better employee relations, and an increased profitability. The purpose of this study is to explore the organisational value of participating in a quality award process. The study is based on interviews at 29 organisations that have participated in the process of the Swedish Quality Award. The main conclusion from this study is that most of the organisations consider the process orientation, customer orientation and improvement work to have been improved as a result of the participation in the quality award process. However, there are also obstacles to surmount in order to benefit fully from the process. Two main obstacles are difficulties in finding resources within the organisation to perform mandatory work and implement identified improvements, and difficulties in applying the circumstantial model used in the quality award process.
\end{abstract}

\section{Introduction}

Japan began honouring quality practices in the 1950s through quality awards. After the successful development in Japan, several countries established programmes in the late 1980s and early 1990s to recognise the inventive, yet effective quality practices taking place, see Vokurka et al. (2000). There are many similarities between different national quality awards, regarding, for example, the criteria and the quality award processes. Some examples of the criteria of quality awards that have been used by many organisations and are widespread are the criteria of the Malcolm Baldrige National Quality Award (MBNQA), see NIST (2003), and the European Quality Award (EQA), see EFQM (2003). In many countries, however, the development of national quality awards is still new or non-existent, see Chuan \& Soon (2000). Vokurka et al. (2000) and Johnson (2002) present a thorough list of quality awards and a comparison between the different awards.

The organisational values for award recipients of participating in a quality award process have been investigated earlier. Hendricks \& Singhal (1997) and Eriksson \& Hansson (2003) compare recipients of quality awards with different control companies. The main conclusion 
from both studies is that companies that have received a quality award outperform the control companies concerning a number of financial measures. Wrolstad \& Kreuger (2001) showed also that companies that had received a quality award presented better results than a control group concerning measures of the operating profit margin, return on sales and return on equity, while the difference was not so large between the two groups concerning the operating margin, but still in favour of the quality award recipients. Quality award recipients like Texas Instruments Defence Group also claim that quality work can yield tremendous rewards, see Junkins (1994).

Many studies published so far which recognise the organisational value of participating in a quality award process have investigated quality award recipients. However, most of the organisations that apply for a quality award never receive any award. An interesting issue for quality award applicants is whether they also, like quality award recipients, benefit from the award process. One of the incentives of applying for a quality award is that improvement areas are identified, which can support actual improvements. The executed improvements can result in, for example, a greater customer orientation, more effective and efficient processes, better employee relations, and an increased profitability of the award applicants. The quality award applicants can therefore benefit in the long run from their application for the quality award as a result of the performed improvements. However, it is not clear how quality award applicants utilize the participation in the quality award process, and how they actually benefit from the performed improvement work. Moreover, it has not been completely investigated what the organisational values are for the quality award applicants that execute improvements successfully, and how much the organisations gain or profit from the improvement work. Hence, the purpose of this study is to explore the organisational value, including both the advantages and the disadvantages, of participating in a quality award process.

\section{Theory}

\section{Total Quality Management}

Total Quality Management (TQM) has become a recognised and frequently discussed term in management literature. Hellsten \& Klefsjö (2000) define TQM, in agreement with the author of this paper, as a management system in continuous change, which consists of values, methodologies and tools, and the aim of which is to increase external and internal customer satisfaction with a reduced amount of resources, see Figure 1. Participating in a quality award process is for many organisations a way to support the management system of TQM. The criteria of quality awards conform with the major constituents of TQM, see Hendricks \& Singhal (1996). Receiving a quality award is also a common proxy for a successful implementation of TQM, see Hendricks \& Singhal (1997), Ghobadian \& Gallear (2001) and Eriksson \& Hansson (2003).

The type of organisations using TQM varies from private to public, large to small and manufacturing to service organisations. However, there is a discussion going on as to whether the general concept of TQM and it values, methodologies and tools should be the same for different types of organisations, for example large and small organisations, see Ehresman (1995). Ghobadian \& Gallear (1997) argue, however, that small organisations can adopt the principles of TQM, but that an implementation of TQM requires specific requirements. Huq $\&$ Stolen (1996) analyse the difference between service and manufacturing organisations, and conclude that the underlying concept of TQM applies equally to both types of organisations, but with the difference that service organisations have been slow to adopt TQM. Similarly, public organisations have been slow to adopt TQM in comparison with private organisations, 
but the concept of TQM is equally important in the two types of organisations, see Dean \& Helm (1996).

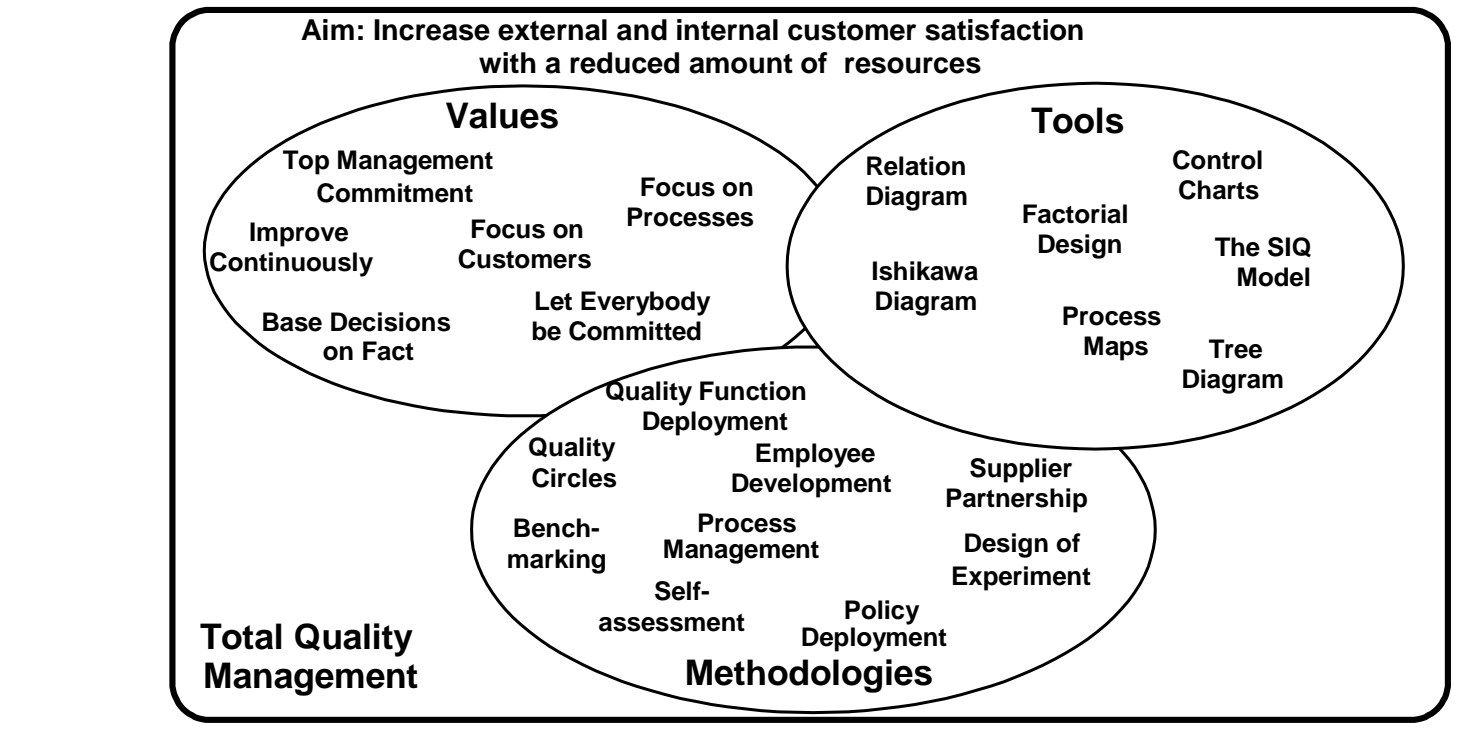

Figure 1 Total Quality Management (TQM) seen as a continuously evolving management system consisting of values, methodologies and tools, the aim of which is to increase external and internal customer satisfaction with a reduced amount of resources. The methodologies and tools in the figure are just examples and not a complete list. Source: Hellsten \& Klefsjö (2000).

\section{Self-assessment}

Self-assessment, which can be regarded as a methodology, see Hellsten \& Klefsjö (2000), has many similarities to the phases that an organisation goes through when participating in a quality award process. The main difference between a quality award process and selfassessment is that the latter does not necessarily involve external examiners. According to EFQM (1996), self-assessment is "a comprehensive, systematic and regular review of an organisation's activities and results referenced against a model of business excellence". Svensson \& Klefsjö (2000) have suggested different phases of self-assessment, which are used in this paper as a description of the quality award process. They argue that the selfassessment procedure has four phases, similar to the four phases of the improvement cycle. The first phase, "plan", includes asking questions like: "Why should we perform a selfassessment?" "When should the work be carried out?" "Who should be involved?" "Which excellence model should be used as a basis for the description?" This phase is developed further by Conti (2002), who claims that the organisation has to ask three questions ("Why?", "How?" and "What?") before initiating self-assessment. The second phase, "do", consists of obtaining a description of the organisation's way of working today. The third phase, "study", consists of the analysis of the description, often resulting in some form of feedback report based on the description. The fourth phase, "act", consists of planning for improvements. The planned improvements are in turn the input to a number of improvement projects that should follow the improvement cycle, see Svensson (2002) and Figure 2. 


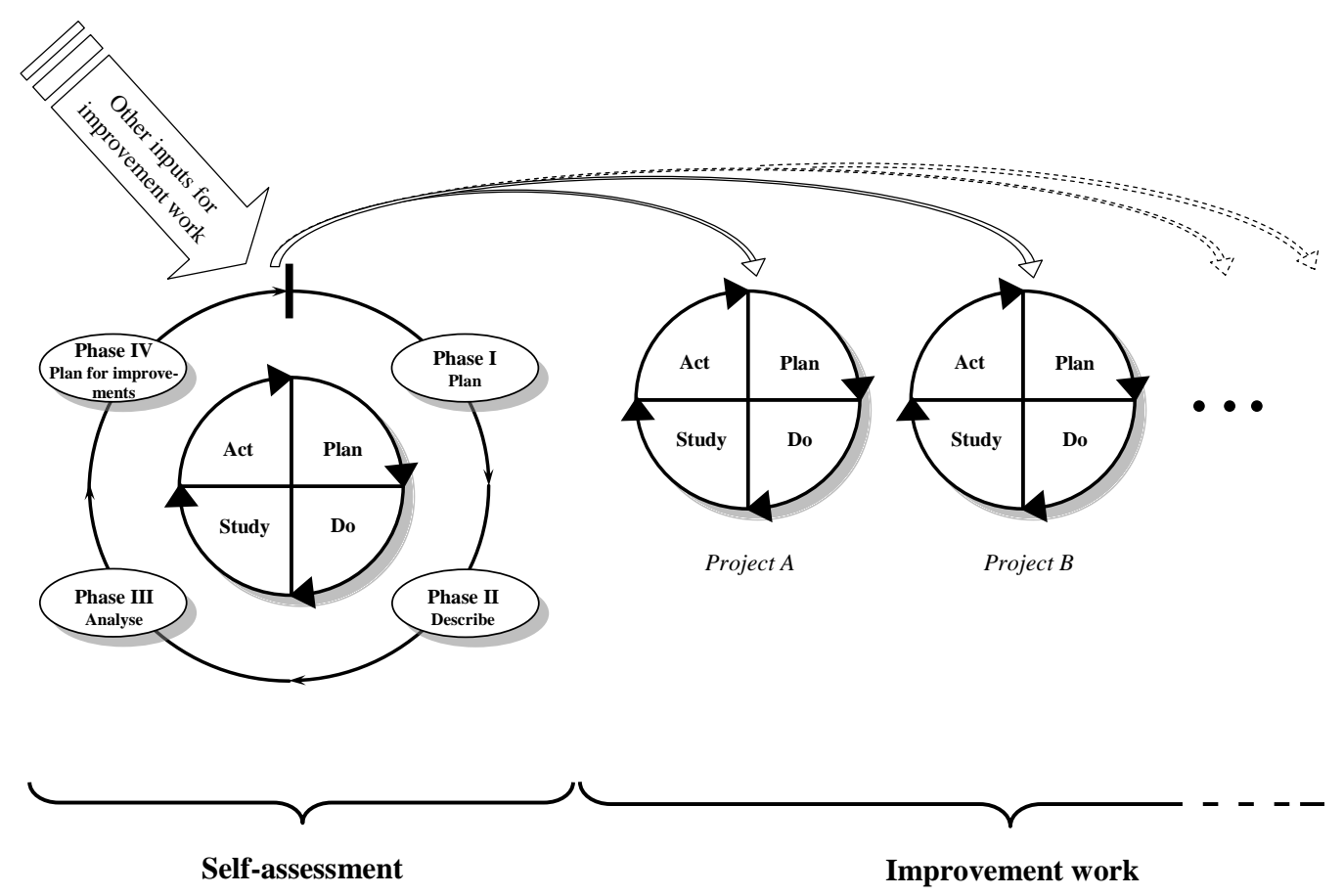

Figure $2 \quad$ Self-assessment and the following improvement work seen as two independent and consecutive processes, each consisting of four phases similar to those in the improvement cycle. Source: Svensson (2002).

The value of self-assessment has been illuminated in earlier research. However, these studies have not necessarily focused on organisations that have participated in a quality award process. For instance, van der Wiele et al. (1996) performed a survey of 117 organisations that had used self-assessment. A number of steps in the self-assessment process were identified to be important as key influences on the success of self-assessment. These were as follows:

- The business unit management develops an improvement plan.

- The outcomes of the self-assessment process are linked to the business planning process.

- Senior management monitors the target for the improvement plan which has been developed.

- The management team of a business unit has to present the improvement plan to the senior management team.

Additionally, van der Wiele et al. (1996) argue that the main learning points of the selfassessment are the following:

- Senior management must be seen to be committed to self-assessment and get involved in the process.

- Senior management has to review the improvement plan which has been set and its implementation.

- The people who will undertake the self-assessment have to be trained.

Furthermore, Finn \& Porter (1994) state, after analysing 29 organisations, that the major benefits from self-assessment are the increase in the focus on improvements and the ability to measure the organisations' progress. Sixteen of these organisations also agreed on the fact that the benefits from self-assessment outweighed the costs associated with the process. The 
benefits of self-assessment recognised by the study performed by Gadd (1995) were within four categories: business results, culture, process management and benchmarking. Ghobadian \& Woo (1994) argue also that self-assessment and taking part in an award process are beneficial. In contrast, Ghobadian \& Woo (1994) also state that the amount of effort required to prepare an application and the large amount of time and high level of financial investment involved are among the major disadvantages of the awards.

Samuelsson \& Nilsson (2002) state, in alignment with Conti (2002), after studying nine large organisations, that there is no universal methodology for self-assessment. On the contrary, their findings indicate that several approaches to self-assessment may be successful, as long as they fit the organisation, are used continuously, and foster participation. Samuelsson \& Nilsson (2002) claim further that self-assessment must be considered from a holistic perspective in order to realise its full potential. Moreover, Conti (1997) argues that selfassessment and the subsequent improvement planning should be integrated into the corporate strategic planning cycle as a first fundamental step in the process of integration of quality concepts into business practice.

Van der Wiele et al. (1997) state in their summary that their research indicates that using the EFQM Model to measure progress is not helpful if an organisation is not experienced in TQM. For example, organisations could be discouraged by the very low scores that may be achieved when using the model.

\section{The Swedish Quality Award}

The Swedish Quality Award is organised by the Swedish Institute for Quality (SIQ). SIQ has developed a model, called the SIQ Model for Performance Excellence, which is based on thirteen core values and seven criteria, which are divided into 27 sub-criteria. The SIQ Model for Performance Excellence is presented in Figure 3.

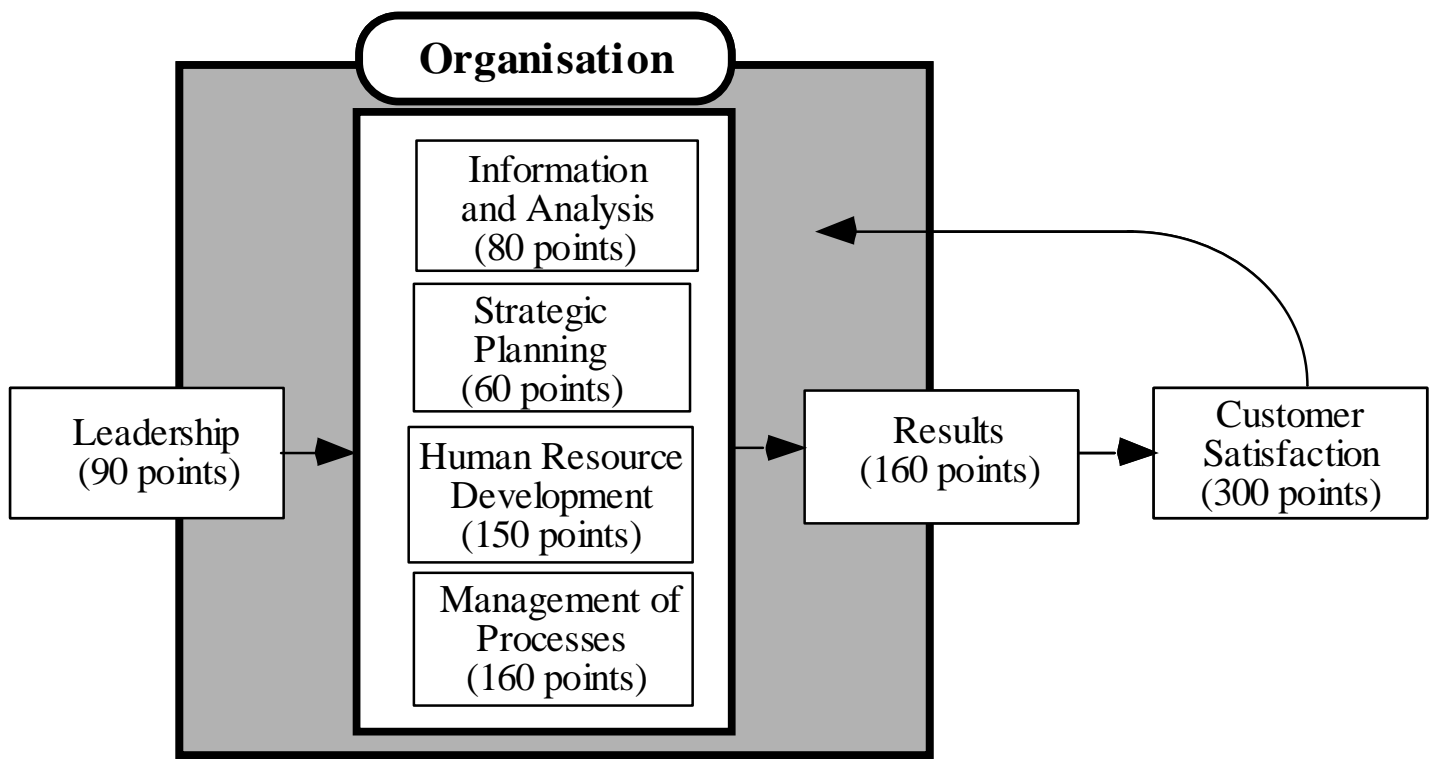

Figure 3 The SIQ Model for Performance Excellence. Source: SIQ (2002).

The core values of the SIQ Model for Performance Excellence, see SIQ (2002), are

- Customer Orientation

- Committed Leadership

- Participation by Everyone 
- Competence Development

- Long-range Perspective

- Public Responsibility

- Process Orientation

- Prevention

- Continuous Improvement

- Learning from Others

- Faster Response

- Management by Facts

- Interaction.

The core values and the number of such values that are included in different quality award models and by different authors of TQM literature differ slightly. For example, the SIQ Model for Performance Excellence includes thirteen core values, while EFQM (2003) only includes eight core values: Results Orientation, Customer Focus, Leadership \& Constancy of Purpose, Management by Processes and Facts, People Development \& Involvement, Continuous Learning, Improvement and Innovation, Partnership Development and Corporate Social Responsibility.

The Swedish Quality Award, which was inspired by the Malcolm Baldrige National Quality Award, see NIST (2003), has also many similarities to the latter. For example, the criteria of both quality awards emphasize the results achieved by the organisations, see Chuan \& Soon (2000). However, one main difference between the Swedish Quality Award and other major quality awards is that the former is mainly based on the SIQ Model for Performance Excellence. Nevertheless, since 2000 it has also been possible to use, in addition to the SIQ Model, the EFQM Model or the MBNQA Model in one's application for the Swedish Quality Award. This is a way to indicate that the methodology is the most important, not the choice of tool. There are also other differences between the Swedish Quality Award and other quality awards. For example, the Swedish Quality Award places greater emphasis on evaluation and improvement with regard to all the criteria addressed and on the practice of TQM principles in all organisational activities. There is also relatively more emphasis on the organisation's impact on society, and on the organisation's commitment to the customers compared with most other national quality awards studied, see Chuan \& Soon (2000). For a thorough discussion concerning the difference between the criteria of the Swedish Quality Award, the Malcolm Baldrige National Quality Award and the European Quality Award, see Puay et al. (1998).

\section{Methodology}

\section{Selection of a Quality Award Process and Time Period}

The purpose of this study was to explore the organisational value of participating in a quality award process. Hence, the first methodology issue to be solved concerned which one of the many quality award processes should be studied. Since the Swedish Quality Award, which is the national quality award and the most frequently applied quality award in Sweden, had not aroused great interest before among researchers, its process was chosen as a relevant quality award process to study. It was originally the author's intention to study all the organisations that had participated in the Swedish Quality Award process. However, it has been possible for organisations to apply for the Swedish Quality Award since 1992. Due to the fact that a long time had passed since the first organisations had applied for the award, the employees within 
these organisations had difficulties in remembering facts and details about the work involved with the quality award. Furthermore, many of the employees within the organisations that had applied during the first years of the quality award had changed jobs and were no longer at the organisations. Hence, the study was limited to organisations that had applied between 1998 and 2002. This limit was set to include as many of the organisations as possible, and yet not decrease the reliability of the study due to the arguments above.

\section{Selection of a Data Collection Method and Organisations}

A total of 46 organisations applied for the Swedish Quality Award between 1998 and 2002. The organisations are located all over Sweden, which would have made face-to-face interviews very resource-consuming. A mail survey was also rejected due to the fact that the non-response rate probably would have been too high. Therefore, phone interviews were chosen as the most appropriate method of data collection.

Not all of the 46 identified organisations were included in the study for different reasons. Three of the organisations that had applied were not allowed to participate in the quality award process, because these organisations did not fulfil the general requirements of SIQ, which administrates the award. An additional nine organisations were excluded from the study because they did not currently exist in the form that they had done when they applied. They had performed a major re-organisation or had been purchased by or merged with another organisation. Hence, it was considered too difficult for these respondents to estimate the organisational value of the quality award process. Furthermore, two organisations did not want to participate in the study, due to a lack of time. In another two organisations, key persons for the study no longer worked at the organisations. It would have been possible to locate these persons, but it would have been very difficult for them to estimate the effects on the organisations of participating in the quality award, since they were no longer at the organisations in question. Finally, one organisation was excluded because it did not fulfil the quality award process and therefore did not receive a feedback report. Hence, the total number of organisations studied, including also some quality award recipients, was 29.

Table I presents how many times the organisations that were included in the study had applied for the Swedish Quality Award. Table I also states whether the organisation was privately or publicly owned, large or small (a large organisation is considered to have more than 200 employees by SIQ) and the type of business (i.e. whether it is a manufacturing or a service organisation).

Table I: $\quad$ The number of times the organisations included in the study applied for the Swedish Quality Award between 1998 and 2002.

\begin{tabular}{|l||c||c||c||c|}
\hline & One time & Two times & Three times & Total \\
\hline \hline Private & 11 & 4 & 2 & $\mathbf{1 7}$ \\
\hline Public & 8 & 4 & 0 & $\mathbf{1 2}$ \\
\hline \hline Large & 10 & 1 & 1 & $\mathbf{1 2}$ \\
\hline Small & 9 & 7 & 1 & $\mathbf{1 7}$ \\
\hline \hline Manufacturing & 4 & 2 & 0 & $\mathbf{6}$ \\
\hline \hline Service & 15 & 6 & 2 & $\mathbf{2 3}$ \\
\hline \hline Total & $\mathbf{1 9}$ & $\mathbf{8}$ & $\mathbf{2}$ & $\mathbf{2 9}$ \\
\hline
\end{tabular}


As shown in Table I, 19 of the organisations had applied once, while eight had applied twice. Only two organisations had applied on three different occasions between 1998 and 2002. If the organisation had applied more than once, the overall experience from participating in the award process was requested during the interviews. Two of these 29 organisations that had applied once had used the EFQM Model in their application. The results concerning the core values and the criteria for these two organisations are therefore not presented in this study, as the criteria and the core values differ slightly between the models.

\section{Selection of Respondents}

The intention of the study was to obtain an overarching view of the organisational value of participating in the quality award process. Hence, the person with overall responsibility for each organisation's application for the Swedish Quality Award was chosen as the most appropriate person to interview. Such a person would be able to present an overview of the work and estimate the overall perceived organisational values of participating in the quality award process. In many cases, the person responsible for the work involved with the quality award was also the CEO of the organisation. One may argue that such a person is biased and unable to present a complete picture of the benefit for the organisation, and that this could influence the results of the study. On the other hand, no other person within the organisation would have been able to present such a complete picture. One way to overcome this problem would have been to interview a number of persons within each organisation. However, this would have been very resource-demanding.

\section{Selection of Inquiries}

The questions used in the phone interviews were developed from questions previously used in studies of internal quality awards, see Eriksson et al. (2003) and Eriksson (2003). One of the findings from Eriksson et al. (2003) shows that the main effects of participating in a quality award are connected to the different core values of the model used. For example, the organisations studied in Eriksson et al. (2003) believed that one effect of internal quality awards was that customer satisfaction was improved. This effect could be linked to the core value of "customer orientation" of the SIQ Model for Performance Excellence. The core values were also illuminated in Eriksson (2003), and were perceived by the author as a good instrument to discover the organisational value of participating in a quality award process. Core values have also been used to illuminate TQM implementation aspects, see Hansson (2003). Hence, the organisational value of participating in a quality award process was measured in the present study through asking about the effects on the core values of the SIQ Model for Performance Excellence. And, in particular, the study illuminated which core values were affected and which were not due to the organisations' participation in the quality award process. In this paper, it is important to distinguish the organisational value, which includes both advantages and disadvantages, from core values, which are the basis of the model used in the quality award process.

In addition, some general opinions on participating in a quality award process were requested from the respondents. Furthermore, the organisations' way of working with the quality award process was investigated using the self-assessment procedure presented in Svensson \& Klefsjö (2000). The major outcome of the award process, the work on improvements that should follow an application, was investigated using the improvement cycle. Questions were asked about each phase of the improvement cycle, see also Figure 2, in order to measure how the organisations had worked with the improvements. 
The interviews were focused, see Yin (1994), and followed a certain set of questions and procedure. The actual phone interviews were performed during March 2003, and all the interviews were recorded. The questions and all the answers have been documented by Eriksson \& Palmberg (2003).

\section{Results}

\section{Quality Award Process at the Organisations}

The organisations' pre-understanding of quality award processes and the SIQ Model varied greatly before entering the quality award process. Some organisations claimed that they had not worked at all with issues that were illuminated in the quality award process, while others had worked with the model for a number of years and participated in other quality award processes; and some had also received a quality award: the Swedish Quality Award, an internal quality award, a regional quality award or a branch-specific quality award. In between these two extreme cases, some organisations had used the SIQ Model to improve the activities and results within the organisation without participating in a quality award process, while other organisations had educated employees within the organisation as examiners in the SIQ model.

Despite the difference in the pre-understanding of the SIQ Model and the experience of participating in a quality award process, the organisations' ways of working with the process of the Swedish Quality Award were similar. In most organisations, different criteria were assigned to different teams with the task of writing the respective criteria. The different criteria were afterwards linked and put together by one or two persons before submitting the application. Some organisations claimed that during the phase of description of activities, improvement potentials were identified and transformed into improvement projects. This work was performed without using the feedback report from the examiners, which is normally considered to be the major input to the improvement work.

The planning for improvement that followed, after the examiners had evaluated the application, was also performed similarly among the organisations. However, some organisations claimed that the description of activities demanded a great deal of resources, and the plan for improvements that was intended to follow did not receive such great attention due to all the resources previously used. When drawing up the plan for improvements, some organisations received help from SIQ and the head examiner to start planning for improvements. Often the improvement areas which had the greatest impact and where it was relatively easy to perform improvements were prioritised among the employees (often including the business management group) who participated during the planning for improvements. Different improvement groups, or quality circles, were often delegated the assignment of executing the improvement. At one quality award recipient, an analysis was performed using the feedback report to identify "Strengths, Weaknesses, Opportunities and Threats" (SWOT). At this organisation the improvements were divided into "quick fixes" and more comprehensive improvement projects.

In several cases the plan for improvements was integrated into the strategic business plan, while in other cases the plan for improvements was kept as a separate activity. The respondents that had integrated the plan for improvement as a part of the business plan believed that the integration was valuable. Some of the organisations that had not integrated the improvement projects into the business plan perceived it too hard to do so. 
Even if many organisations in the study planned systematically for the improvements, not all the organisations actually performed the different prioritised improvement projects. Some organisations had recently applied for the quality award and therefore had not yet performed all the identified improvement projects. However, there was also a group of organisations that did not succeed with the improvement projects or at least had not yet performed them after a number of years. Restriction of resources was the main explanation for not performing the improvement work.

Furthermore, the organisations that actually performed improvements based on the plan for improvements were not always as systematic as they had been in the initial step when planning for the improvements. Especially during the follow-up phases, including studying the outcome of the improvement and acting on the basis of it, see Figure 2, many organisations were not very systematic. Several organisations planned and executed the improvement, but failed to follow up the improvement in question. These organisations did not measure whether the improvements had the desired effect. This is especially true when it comes to translating the improvements into monetary value. No organisations claimed that they had measured how much they had earned in monetary units from the executed improvements. Many organisations claimed that it was too difficult, and some that it was even impossible, to estimate on the basis of the performed improvements how much they had earned in monetary units. In particular, the respondents found it hard to separate the activities related to the participation in a quality award process from other improvement activities performed within the organisation. However, a few organisations stated that they performed better than other organisations in the industry and other comparable organisations with regard to a number of indicators, including customers, employees and financial measures.

\section{Organisational Advantages of the Quality Award Process}

The overall attitude to the organisations' participation in the quality award process was positive. The organisation's attitude was measured using a five-grade scale: very negative, negative, neither negative nor positive, positive, and very positive. Twenty-six organisations were either positive or very positive to the organisations' participation in the quality award process, with a small favour for the positive alternative. A few organisations also claimed that they would participate in a quality award process in the future.

One major benefit of participating in a quality award process is, according to the respondents, that one obtains an external evaluation of the business, and a confirmation and assessment of the current position of the business in comparison with, for example, the organisation's goals, competitors and best-in-class organisations. Furthermore, the participation in the award process in itself resulted in a stronger participation by everyone and a common goal to work towards. Moreover, an increased focus on improvements was mentioned as a result of participating in the quality award process. The process was also an important learning experience for the employees who were involved in the quality award process.

Another advantage of participating in a quality award process, according to the respondents, was a better structure in the business' activities, which in return resulted in a more comprehensive and systematic approach. The SIQ Model was believed to be complete, to cover the whole business, and to ensure that no area or issue was neglected. Furthermore, many award applicants that were beginners, i.e. organisations that had no extensive previous knowledge about TQM, believed that the SIQ Model resulted in a new thinking in the organisations. This was due to the fact that the employees were trained in and were required to work with the SIQ Model. Furthermore, experience of the SIQ Model was considered to be 
an advantage when working with other standards, for example ISO 9000:2000 and Investor in People (IIP), as the threshold was not that high once one had worked with TQM. The new ISO standard, ISO 9000:2000, has a stronger focus on processes in comparison with the previous version. Through the work performed with the SIQ Model, which has a strong focus on processes, the transition to ISO 9000:2000 was easier according to one of the respondents.

\section{Analysis of the Core Values}

As mentioned above, the core values were illuminated as they were regarded as an important aspect when considering the benefits of participating in a quality award process. The issue that was illuminated was whether the respondents considered the 13 core values of the SIQ Model to be improved due to the participation in the quality award process.

Overall, most of the respondents believed that the greatest impact of participating in the quality award process was on the core value of "customer orientation". Secondly, "continuous improvement" and "process orientation" were considered to be the most improved core values. Some quality award applicants also believed that the core values of "participation by everyone" and "committed leadership" had improved most.

When asking and analysing whether the different core values had improved at all as a result of the participation in the award, some core values were considered to have been improved, while others were not. The results for all the core values included in the SIQ Model are presented in Figure 4, 5 and 6. Two organisations were not included in this analysis due to the fact that they had used the EFQM Model in their application. In addition, one organisation was excluded from this analysis because the respondent was not able to estimate whether the core values were improved or not.

As shown in Figure 4, 5 and 6, all the organisations in the analysis believed that the organisation's "process orientation" had improved due to the participation in the quality award process. Furthermore, "customer orientation" and "continuous improvement" were also considered to have been improved by most of the organisations. "Committed leadership", "participation by everyone" and "management by facts" were by a relatively high number of respondents also considered to have been improved. The core value "long-range perspective", on the other hand, was only considered to have been improved by a few organisations. "Public responsibility" and "faster response" were also only considered by a few organisations to have been improved as a result of the participation in the award process.

The impact of the criteria due to the participation in a quality award process was also illuminated. The criteria of "customer satisfaction", "process management" and "strategic planning" were the criteria considered to be most improved as a result of the participation in the quality award process. These results reinforce the picture that it is in the areas of processes and customers that the greatest impact is achieved when applying for a quality award. Surprisingly, "strategic planning" was also considered as a criterion that was affected to a large extent. This might have been due to the fact the respondents were in many cases the CEO. The CEO often works with strategic planning, and therefore may see the impact largely in this area. Strategic planning is also strongly related to systematic and structured work, which was considered as one of the main advantages of participating in a quality award process.

Figure 4, 5 and 6 also present which type of organisation had the greatest benefit from participating in a quality award process when considering the core values. In Figure 4, public 
organisations are compared to private organisations. Public organisations believed to a larger extent that the core values had improved. This is especially true of the core values of "competence development" and "learning from others". All the public organisations also believed that the core value "participation by everyone" was affected by the quality award process. On the other hand, the public organisations did not believe to a large extent that "public responsibility" had improved, which should be one of their main objectives.

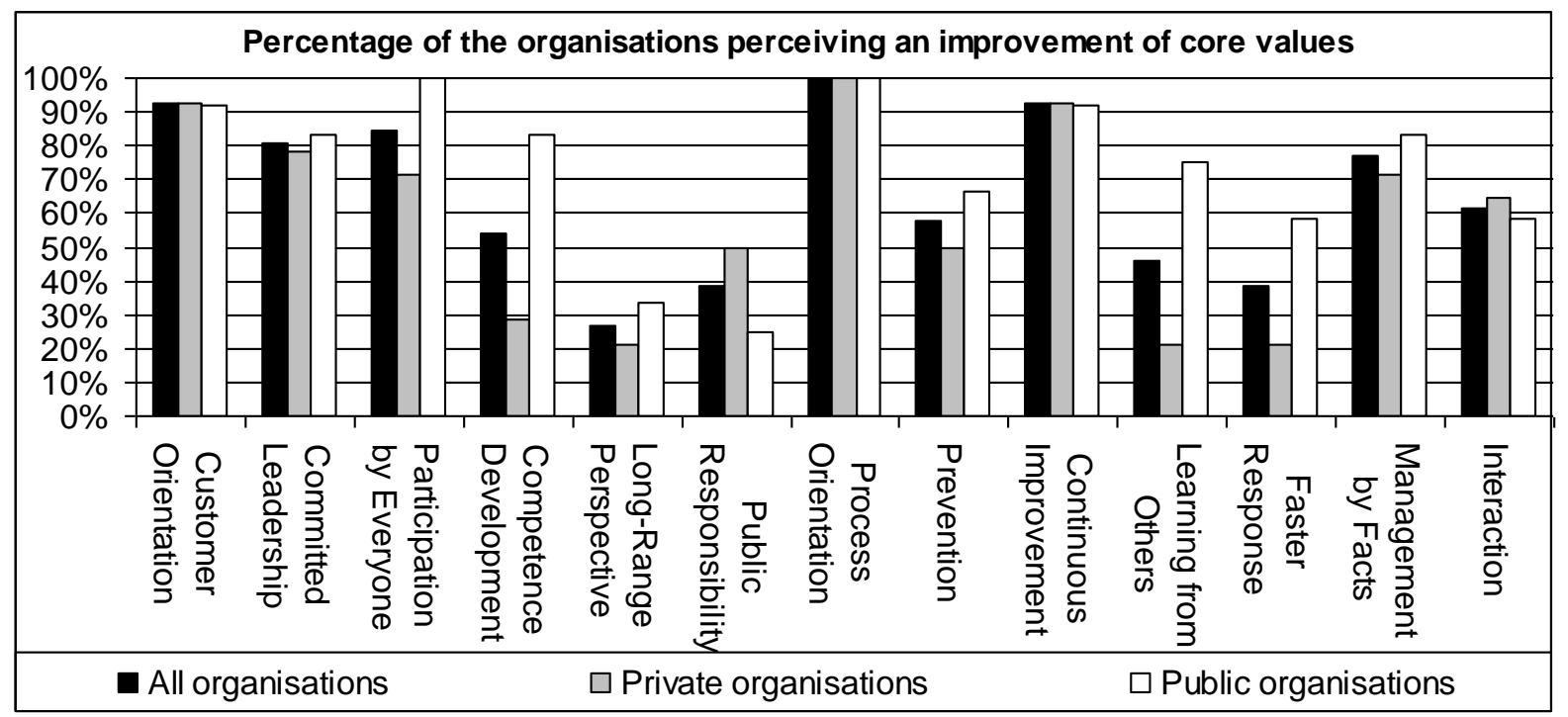

Figure 4 The percentage of the 26 organisations, the private organisations and the public organisations perceiving the core values to have been improved as a result of participating in the quality award process.

When studying the impact of participating in the quality award process on the core values, it seems that the size of the organisation does not matter, see Figure 5. Large organisations and small organisations believed, to a relatively large extent, that the same core values were improved as a result of the quality award process.

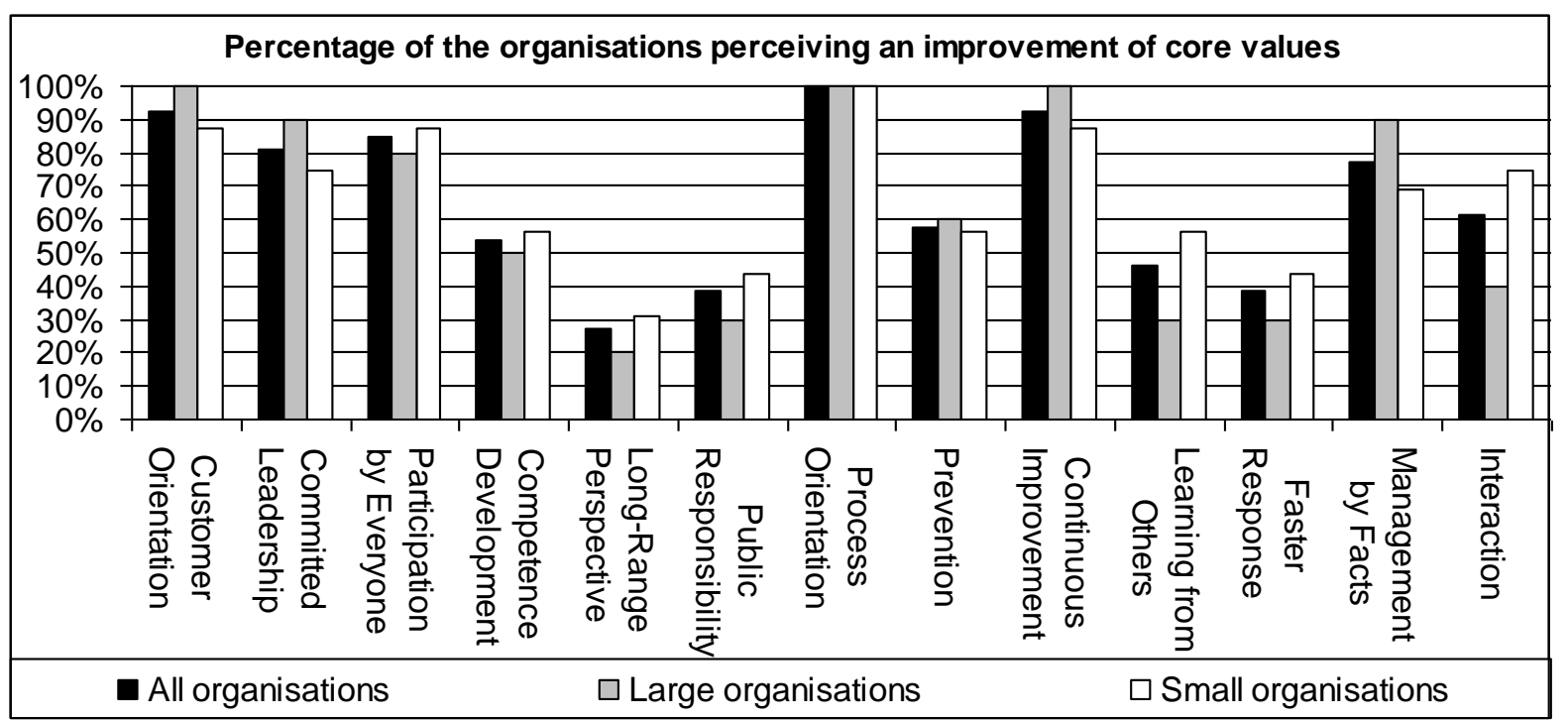

Figure 5 The percentage of the 26 organisations, the large organisations and the small organisations perceiving the core values to have been improved as a result of participating in the quality award process. 
Figure 6 also compares differences concerning the improvement of core values between the manufacturing and the service organisations. With small differences, both types of organisations believed that the same core values were affected by the quality award process.

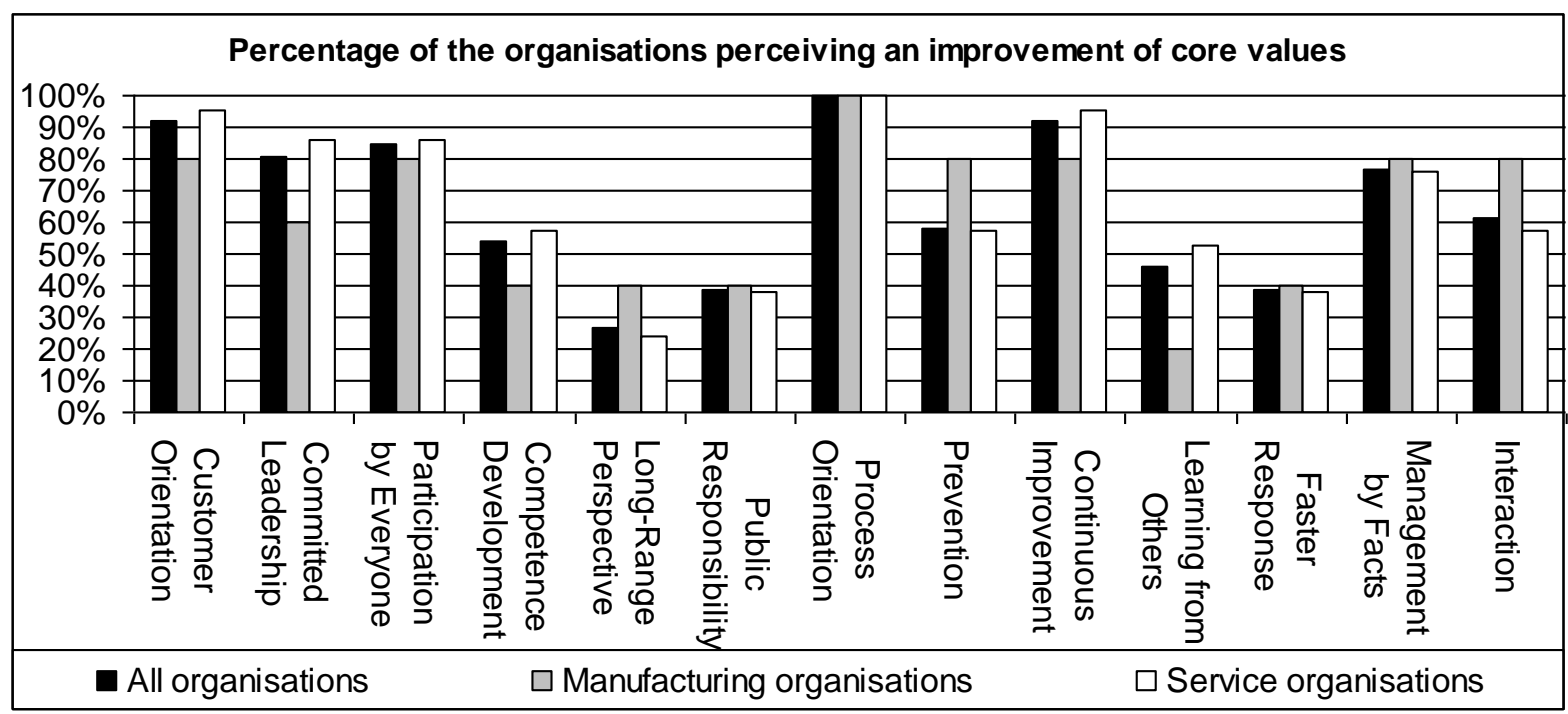

Figure 6 The percentage of the 26 organisations, the manufacturing organisations and the service organisations perceiving the core values to have been improved as a result of participating in the quality award process.

As reflected in Figure 4, 5 and 6, different core values are impacted differently by the award process. Some core values are considered to have been improved by almost all the organisations, while only some organisations consider other core values to have been improved. These differences can depend on either the model or the organisations adopting the model. The SIQ Model may emphasise some core values more than others, even if no core value is expressed to be more important explicitly in the model. Similarly, the organisation can neglect some core values and favour others during the quality award process. The organisation's pre-understanding of TQM and the core values may also influence which of the core values the organisation believes were improved as a result of the quality award process.

\section{Organisational Disadvantages of the Quality Award Process}

The main disadvantage of participating in the Swedish Quality Award was the resourcedemanding and time-consuming work that organisations were required to perform when participating in the quality award process. In particular, the time-consuming phase of description of activities took the focus away from the operative activities. As a result of this time-consuming phase, the improvement work that should follow was also neglected, according to a few respondents.

The SIQ Model also received criticism for being too abstract and circumstantial, and difficult to use for beginners. Furthermore, the language and the definitions were hard to understand, according to the respondents. As a result, the work performed with the SIQ Model was difficult to communicate to the employees who were not involved with the work. Consequently, some employees within the organisations had difficulties in following the process, and instead chose to be very critical. Two organisations claimed further that the SIQ Model did not fit all organisations. For example, one public organisation stated that the SIQ Model did not fit the public sector. Instead that organisation preferred the EFQM Model, as a better tool for public organisations. Another organisation claimed that the SIQ Model did not 
fit non-profit-driven organisations within the service sector. Two organisations also believed that the SIQ Model only fitted manufacturing organisations.

Two organisations that had applied with the one incentive of receiving an award also felt that they had been misunderstood by the examiners, as they did not receive the award. The disappointment among the employees spread, which led to quality issues not being prioritised any longer. The quality assurance of the examiners evaluating the organisations was another area that received criticism from the participating organisations. Two organisations that had applied more than once for the quality award perceived that the feedback report differed too much, and that the grading system was not reliable. They claimed further that it was hard to find improvement areas based on the feedback report from one group of examiners. Furthermore, they believed that the level of knowledge of the examiners had to be increased. Another quality award applicant made a comparison with the European Quality Award, and stated that the feedback report from the examiners for this award was a more powerful tool to use in order to improve one's business.

The quality award recipients did not always consider the quality award announcement beneficial to the organisation. If an organisation receives the award, the organisation is obligated to perform certain activities, such as having an open house and holding seminars. Furthermore, many other organisations want to benchmark the organisation. Two small organisations that had received the quality award expressed that the work that followed the quality award announcement was too much for small organisations, as they did not have enough resources to handle this extra work. Everyday activities were therefore to some extent neglected within these organisations, and it was impossible to find time for improvement work. One quality award applicant claimed that the whole idea about learning from others was neglected, as one could not benchmark other organisations that had participated in the quality award process, except for the quality award recipients, because the organisations applying for the award were anonymous.

\section{Discussions}

Previous studies have shown that there is a positive relationship between TQM and performance, see Hendricks \& Singhal (1997) and Eriksson \& Hansson (2003). However, no organisations claimed that they had estimated how much they had earned in monetary units from the executed improvements, which is a common approach among other improvement programmes, for example, the Six Sigma, see Magnusson et al. (2003). Still, the value of TQM, through participating in a quality award process and performing self-assessment, seems to be beneficial according to the respondents of this study and in alignment with, for example, Finn \& Porter (1994) and Eriksson et al. (2003). In agreement with earlier studies of selfassessment, the major benefits of participating in a quality award process are a greater focus on improvement work, see Finn \& Porter (1994) and van der Wiele et al. (1996), processes, see Gadd (1995), and customers, see Brown \& van der Wiele (1996) and Eriksson (2003). In addition, participation in a quality award process is also perceived to have an impact on "committed leadership", "participation by everyone" and "management by facts". These six areas or core values are also considered to be the essence of TQM today, see Bergman \& Klefsjö (2003). Furthermore, this study, Ghobadian \& Woo's (1994) study of self-assessment and Eriksson (2003) show that the major disadvantage of participation in quality awards is the resource-demanding and time-consuming work required.

Overall, it seems that the type of organisation does not influence the outcome of the quality award process to a large extent, even if some organisations claimed that the SIQ Model only 
fitted certain types of organisations. Public organisations believed, however, to a larger extent than private organisations that the core values were improved. This could be due to the fact that public organisations have been slow to adopt TQM, see Dean \& Helm (1996), and have therefore more to gain initially from the quality award process. Private organisations may have been working with TQM for a longer time and may therefore not benefit from the quality award process to the same extent as public organisations. However, van der Wiele et al. (1997) claim that beginners do not benefit from the use of the EFQM Model. In contrast, it seems that beginners in TQM experience the organisational value of the quality award process differently compared to more experienced users of TQM. Beginners benefit largely from the introduction of TQM because it results in a new way of thinking and a valuable experience for the involved employees, which are of great use in a longer perspective. On the other hand, it seems that organisations that already have great experience of TQM benefit to a larger extent from the actual outcome of the quality award process, the improvement work.

Even though some award applicants claimed that they would not participate in the quality award process in the future, they found the experience valuable. Some award applicants also believed that the quality issues that were raised when participating in the quality award process were important. These issues would not be neglected, even if the organisations did not intend to participate in a quality award process in the future, according to some respondents. In particular, these organisations claimed that there was a difference between the tool of the SIQ Model, whose value could be discussed, and the management system of TQM, which could never be neglected within organisations. Furthermore, some of the respondents claimed that applying for a quality award took the focus away from improvement, which should be the major outcome of an award, and that the focus was instead on the competition. This problem is also discussed in Conti (2002), who claims that if one's aim is to improve, the best choice is not to apply for a quality award.

Some quality award applicants found it hard to make a breakthrough in their quality revolution and therefore did not yet see fully the value of working with TQM, while other organisations had already surmounted the obstacles and benefited greatly from the concept. Even if these organisations had overcome the major barrier of implementing TQM, it was difficult for them to maintain their new position. This was especially true within organisations which had lost some of the employees most dedicated to TQM. To eliminate the possibility of losing ground, one quality award recipient claimed that the quality award process was used annually, internally or through participation in the Swedish Quality Award process, to assure that the organisation maintained what it had accomplished earlier.

All the answers from the respondents are presented in Eriksson \& Palmberg (2003) in order to make repeatability possible. To increase the validity of the present study, the quality award process was explained to the respondents in order to decrease possible misinterpretations. An internal validation was executed as well, in which colleagues of the author and a project group commented on the structure and the questions that were going to be asked during the phone interviews.

In future research, a more in-depth study will need to be performed in order to realise fully the value of participating in a quality award process. Furthermore, such in-depth studies will need to study how the improvement work should be performed. This could be accomplished by studying successful organisations, regarding the improvement work, in order to understand fully the possible benefits of participating in a quality award process. Furthermore, these 
studies will need to illuminate why some core values are perceived to be improved while others are not.

\section{Conclusions}

The quality award applicants experienced a great benefit from participating in the award process. The main conclusion from this study is that most of the organisations considered the process orientation, customer orientation and improvement work to have been improved as a result of the participation in the quality award process. However, there are also obstacles to surmount in order to benefit fully from the process. Two main obstacles are difficulties in finding resources within the organisation to perform mandatory work and implement identified improvements, and difficulties in applying the circumstantial model used in the quality award process.

\section{Acknowledgements}

The author gratefully acknowledges the financial support from the Department of Economic Statistics at Stockholm School of Economics, "Söderbergstiftelsen" and "Carl Tryggers Stiftelse för vetenskaplig forskning". The extensive support from the project group, consisting of Professor Bengt Klefsjö at Luleå University of Technology, and Professor Jan Eklöf and Dr. Johnny Lindström at Stockholm School of Economics, is also acknowledged. The author would also like to thank Dr. Rickard Garvare and Klara Palmberg at Luleå University of Technology for their support.

\section{References}

Bergman, B. and Klefsjö, B. (2003). Quality from customer needs to customer satisfaction. Lund, Sweden, Studentlitteratur.

Brown, A. and van der Wiele, T. (1996). "Quality management self-assessment in Australia." Total Quality Management 7(3): 293-307.

Chuan, T. K. and Soon, L. C. (2000). "A detailed trends analysis of national quality awards world-wide." Total Quality Management 11(8): 1065-1088.

Conti, T. (1997). "Optimizing self-assessment." Total Quality Management 8(2/3): 5-15.

Conti, T. (2002). A road map through the fog of quality and organizational assessments. Proceedings from the 7th World Congress for Total Quality Management: Business excellence. Make it happen. June 25-27 2002. Verona, Italy, University of Verona, Faculty of Economics:9-21.

Dean, M. B. and Helm, M. M. (1996). "The implementation of Total Quality Management into public sector agencies. A case study of the Tennessee Valley Authority." Benchmarking for Quality Management \& Technology 3(1): 50-64.

EFQM (1996). Self-assessment. Guidelines for companies. Brussels, The European Foundation for Quality Management (EFQM).

EFQM (2003). EFQM Excellence Model. Brussels, The European Foundation for Quality Management (EFQM). 
Ehresman, T. (1995). Small business success through TQM. Milwaukee, WI, ASQC Quality Press.

Eriksson, H. (2003). "Experiences of working with in-company quality awards." The TQM Magazine 15(6). To be published.

Eriksson, H. and Hansson, J. (2003). "The impact of TQM on financial performance." Measuring Business Excellence 7(1): 36-50.

Eriksson, H., Johansson, F. and Wiklund, H. (2003). "Effects of in-company quality awards on organisational performance." Total Quality Management \& Business Excellence 14(2): $235-242$.

Eriksson, H. and Palmberg, K. (2003). Erfarenheter från utmärkelseprocessen till Utmärkelsen Svensk Kvalitet (USK). Research Report 2003:4. Luleå, Sweden. Division of Quality \& Environmental Management, Luleå University of Technology.

Finn, M. and Porter, L. J. (1994). "TQM self-assessment in the UK." The TQM Magazine 6(4): 56-61.

Gadd, K. W. (1995). "Business self-assessment. A strategic tool for building process robustness and achieving integrated management." Business Process Re-engineering \& Management Journal 1(3): 1355-2503.

Ghobadian, A. and Gallear, D. (1997). "TQM and organisational size." International Journal of Operations \& Production Management 17(2): 121-163.

Ghobadian, A. and Gallear, D. (2001). "TQM implementation. An empirical examination and proposed generic model." Omega 29(4): 343-359.

Ghobadian, A. and Woo, H. S. (1994). "Characteristics, benefits and shortcoming of four major quality awards." International Journal of Quality and Reliability Management 13(2): $10-44$.

Hansson, J. (2003). Total Quality Management. Aspects of Implementation and Performance. Investigations with a focus on small organisations. Doctoral Thesis. Luleå, Sweden. Division of Quality \& Environmental Management, Luleå University of Technology.

Hellsten, U. and Klefsjö, B. (2000). "TQM as a management system consisting of values, techniques and tools." The TQM Magazine 12(4): 238-244.

Hendricks, K. B. and Singhal, V. R. (1996). "Quality Awards and the market value of the firm. An empirical investigation." Management Science 42(3): 415-436.

Hendricks, K. B. and Singhal, V. R. (1997). "Does implementing an effective TQM program actually improve operating performance? Empirical evidence from firms that have won quality awards." Management Science 43(9): 1258-1274. 
Huq, Z. and Stolen, J. D. (1996). "Total Quality Management contrast in manufacturing and service industries." International Journal of Quality and Reliability Management 15(2): 138161.

Johnson, C. N. (2002). "Annual quality awards listing." Quality Progress 35(8): 48-57.

Junkins, J. (1994). "Insights of a Baldrige Award winner." Quality Progress 27(3): 57-58.

Magnusson, K., Kroslid, D. and Dahlgaard, J. (2003). Six Sigma. The pragmatic approach. Lund, Sweden, Studentlitteratur.

NIST (2003). Criteria for performance excellence. Gaithersburg, MD, National Institute of Standard and Technology.

Puay, S. H., Tan, K. C., Xie, M. and Goh, T. N. (1998). "A comparative study of nine national quality awards." The TQM Magazine 10(1): 30-39.

Samuelsson, P. and Nilsson, L. E. (2002). "Self-assessment practices in large organisations. Experiences from using the EFQM excellence model." International Journal of Quality \& Reliability Management 19(1): 10-23.

SIQ (2002). The SIQ model for performance excellence. Gothenburg, Swedish Institute for Quality (SIQ).

Svensson, M. (2002). TQM-based self-assessment in educational organisations. Licentiate thesis. Luleå, Sweden, Luleå University of Technology.

Svensson, M. and Klefsjö, B. (2000). "Experience from creating a quality culture for continuous improvements in the Swedish school sector by using self-assessments." Total Quality Management 11(4/5\&6): 800-807.

van der Wiele, A., Williams, A. R. T., Dale, B. G., Carter, G., Kolb, F., Luzon, D. M., Schmidt, A. and Wallace, M. (1996). "Self-assessment. A study of progress in Europe's leading organizations in quality management practices." International Journal of Quality and Reliability Management 13(1): 84-104.

van der Wiele, A., Dale, B. G. and Williams, A. R. T. (1997). "ISO 9000 registration to total quality management. The transformation journey." International Journal of Quality Science 2(4): 236-252.

Vokurka, R. J., Stading, G. L. and Brazeal, J. (2000). "A comparative analysis of national and regional quality awards." Quality Progress 33(8): 41-49.

Wrolstad, M. A. and Kreuger, T. M. (2001). "Study shows that quality pays winners." The Total Quality Management Forum 27(3): 14-16.

Yin, R. K. (1994). Case study research. Design and methods. Thousand Oaks, California, Sage Publications. 